\title{
POTENTIAL OF GAMIFICATION FOR LEAN CONSTRUCTION TRAINING: AN EXPLORATORY STUDY
}

\author{
Carla Pütz $^{1}$, Gunnar J. Lühr ${ }^{2}$, Mona Wenzel ${ }^{3}$, and Manfred Helmus ${ }^{4}$
}

\begin{abstract}
For several years, Lean Construction has been an established management approach in the construction industry. Despite the high popularity of Lean Construction, the philosophy is far from being applied in all companies and projects. When changing the construction management methods, the use of Lean Construction represents a massive transformation of working methods and project culture. Studies show examples of failed implementations of Lean Construction and barriers like lacking understanding of Lean Construction methods. Thus, accompanying change by systematic change management processes is important in order to implement it successfully in the long term. Efficient and targeted training to enable the workforce to apply Lean Construction methods is one way to foster the change.

Gamification supports a motivating design of such training. The concept pursues the game-like design of non-game contexts to transfer the motivation gamers show in videogames to those non-game contexts. Despite its success in other industries, gamification has not been used frequently in the construction industry. Nevertheless, approaches of the concept are already included in Lean Construction training. In this paper we propose an exploratory study to improve the effectiveness of training on Lean Construction using Gamification. Various trainings on different Lean Construction methods like the Last Planner ${ }^{\circledR}$ System, takt planning and takt control, 5S and A3, were observed and show the potential of gamification for Lean Construction, but also room for improvements. The presented exploratory study provides guidance for the integration of gamification in Lean Construction training. Applying the concept of Gamification can improve the learning outcome of trainings and employee's motivation to use Lean Construction methods.
\end{abstract}

\section{KEYWORDS}

Lean construction, gamification, training, change management.

$\mathrm{PhD}$ student, civil engineering, dept. construction management, University of Wuppertal, Germany, +49 202439 4190, puetz@ uni-wuppertal.de, orcid.org/0000-0002-0793-1428

$2 \mathrm{PhD}$ student, Alma Mater Europaea - ECM, Maribor, Slovenia, +386 2/250 1997, gunnar.luhr@almamater.si, orcid.org/0000-0002-7288-6133

3 Student, civil engineering, dept. construction management, University of Wuppertal, Germany, +49 202439 4190, mowenzel@ zechbau.de, orcid.org/0000-0002-8607-8911

4 Professor, civil engineering, dept. construction management, University of Wuppertal, +49 202439 4412, helmus@uni-wuppertal.de, orcid.org/0000-0002-5421-9142 


\section{INTRODUCTION}

During recent years, Lean Construction has established itself as an approach to the management of construction projects. 'Lean Construction' is the construction industry's attempt to implement the principles of Lean Manufacturing into the construction industry under consideration of its unique circumstances (Fiedler 2018). Lean management focusses especially on customer satisfaction by eliminating waste through continuous improvements of all processes (Liker and Morgan 2006). Different applications and principles were already in-depth presented and discussed, especially at the past 28 conferences of the 'International Group for Lean Construction' and the belonging proceedings.

Salem et al. (2006) summarise that especially the IGLC community is responsible for the emergence of Lean Construction techniques and approaches that changed and improved ways of planning, controlling, supply chain management and applications of visualisation techniques. Overall, those developments lead to continuous improvement. Despite these achievements, studies like Demirkesen et al.'s (2019) report barriers in introducing Lean Construction and results of poor implementation attempts. 'Continuous improvement' can be equated with 'continuous change' and implementing this continuous change of known working methods creates cultural issues such as the resistance to change (Demirkesen et al. 2019). Therefore, successful change management is required and essential for organisations to survive (Song 2009). Scholars frequently report from high failure rates of change management programs from 50 (Schaffer and Harvey 1992) to $70 \%$ (Balogun and Hailey 2008; By 2005).

These numbers underline the importance of careful preparation and well-thought-out introduction processes for the implementation of Lean Construction. As the philosophy of Lean Construction itself states, people should be the focus of process consideration. This philosophy is shared by change management. An essential part of change management is the training of employees (Kotter 1996). For Lean Construction methods such as the Last Planner® System, studies show remaining critical socio-technical barrier in the implementation. Despite training the lack of understanding principles and methods prevails (Liu et al. 2020).

With focus on the empowerment of employees through training within the change management process, gamification is a concept that is particularly suitable to face those barriers. Gamification, derived from the word "game", is a fairly young concept that transfers the enthusiasm and engagement generated for video games, into other contexts. For this purpose, elements from games such as points, stories or levels are implemented into an everyday context like a learning environment (Deterding et al. 2011a, 2011b). Whether consciously or unconsciously, Lean Construction training already contains elements of gamification. Expanding those elements further offers great potential for improved Lean Construction implementation. Liu et al. already showed the potential of serious games for Lean Construction training in their paper on promoting the Last Planner® System through virtual reality and serious games (Liu et al. 2020). Further approaches to use serious games in the context of Lean Construction are provided by Tommelein et al. (1999) and Sacks et al. (2007). Complementary to the serious game approaches, several innovative ways of teaching lean construction have already been introduced by Tsao et al. (Tsao et al. 2013). Since the creation of serious games requires a lot of programming effort, as a further approach this paper focusses on the concept of gamification. 
Based on the importance of training for successful change management processes, this paper will conceptually discuss the potential of gamification for Lean Construction training. Through literature review and observation of Lean Construction training, we analyse the gamification approaches already included in Lean Construction training. Concluding, we identify the potential for extending these approaches. We seek to advance the understanding of the potential of gamification for Lean Construction training by presenting a conceptual framework as a guide for the application of gamification in Lean Construction.

\section{IMPLEMENTATION OF LEAN CONSTRUCTION VIA CHANGE MANAGEMENT PROCESSES}

Generally applicable instructions for the implementation of innovations in companies are difficult to define, as companies differ greatly in their structure and culture. In addition, the human factor within the company is decisive for success and must be considered individually (Lauer 2010). The ideas of change management provide a basic guideline for the successful design of innovation introduction processes with a focus on the human factor (Kotter 1996). Change management is the management to fundamentally change corporate strategies and structures to new framework conditions (Schewe 2018). It describes the ideal design of the path from the starting point to the goal of change (Lauer 2010). Change management is directed inwards, i.e. towards the members of an organisation that is changing. In contrast, strategic management is directed towards the environment in order to achieve optimal adaptation. (Lauer 2010)

Phase 5 "empowering employees for board-based action" of Kotter's change management model emphasises the importance of employee training in the sense of "empowerment" as an important step in the implementation of Lean Construction. Efficient and targeted training of employees should therefore be given special attention in the implementation of change management processes around Lean Construction.

As studies show, training on Lean Construction has not always led to success so far and has left behind barriers to implementation. (Demirkesen et al. 2019; Liu et al. 2020) As an alternative approach to conventional training, we identify and discuss the potential of gamification for Lean Construction training. To this end, we introduce the concept of Gamification, which has been fairly used in the construction industry so far.

\section{Gamification in a Training ConteXt}

Gamification is a concept that developed from the enthusiasm for games. Games convey feelings of challenge, success and engagement to a greater extent than everyday life, which leads to gamers playing games with high motivation and commitment (McGonigal 2012). People play games of their own free will, with high intrinsic motivation. Above all, the growing success of videogames means that the game industry today no longer only captivates children and young people (Rechsteiner 2020). Around 2.5 billion people worldwide regularly play computer or video games. The average age of gamers is now 37 , $15 \%$ of gamers are already 60 or older (statista 2020). Transferring this enthusiasm for games to other contexts is the idea of gamification (Sailer 2016). Motivating elements of games are used in non-gaming areas, outside the usual function of games. These areas can be everyday situations like shopping, work or learning processes (Deterding et al. 2011a). Gamification is therefore not limited to training contexts. However, numerous studies show positive effects of gamification in this context (see Hamari et al. 2014; Seaborn and Fels 2015). 


\section{Concept of Gamification}

The most commonly used definition of gamification is Deterding et al.'s (2011a), describing gamification as the use of game design elements in non-game contexts. In contrast to serious games, for example, gamification does not refer to fully-fledged games, but only to the use of various game design elements that are characteristic building blocks of games (Sailer 2016). Important for gamification approaches is the intentional use of game design elements to make an experience more game-like (Sailer 2016).

The following examples explain the idea of using game design elements in non-game contexts. Game elements that are particularly present in everyday life are, for example, points, rankings, a narrative or badges. In sports games like football, points often determine who wins a championship. By comparing the points of all teams, rankings are created that simultaneously visualise the value of the points. In the form of a gamification approach, points are used in frequent flyer programmes or as loyalty points. Here, the non-game context is everyday shopping. Medals in sport are badges that reflect a certain success. In a context unrelated to games, badges are used in the military to visualise ranks or special achievements (Schöpper et al. 2019). Embedding a narrative in a non-game context, is unconsciously used by parents in upbringing. Aeroplane landing at feeding time or crocodiles on the ground, making skipping from stone to stone on the way home more motivating, are examples of this.

Literature on gamification shows that it is important not to reduce gamification concepts to the application of the beforementioned common game design elements. Simply adding points, rankings and badges to an existing context does not lead to increased motivation or positive effects in the long term (Morschheuser et al. 2018). The game-like design as an intention is crucial for the success of gamification (Sailer 2016). In order to apply gamification successfully, game design elements must be used in a targeted way. The participants must be analysed, the context and the effect of the game design elements must be taken into account (Morschheuser et al. 2018).

Positive results achieved by the use of gamification in training are reported by several studies. Achieved effects are higher motivation and better performance (Sailer 2016), improved engagement, enjoyment and learning, higher participation and increased contributions (Seaborn and Fels 2015).

\section{Approaches of Gamification in Lean Construction Trainings}

As discussed above, the intention to design a game-like experience is mandatory for a gamification concept. Simply using game design elements without strategy can fail their effect. Though Lean Construction training does not implement gamification intentionally yet, approaches are already visible. Through the observation of several Lean Construction trainings, we outline those approaches, highlighting the potential for the intentional use of gamification.

In the course of the observation, we analysed eight trainings conducted both by internal and external consultants. The trainings focussed on four different Lean Construction methods: Last Planner® System (three observed trainings), takt planning and takt control (three observed trainings), 5S (one observed training) and A3 (one observed training). The trainings were carried out with different training methods to provide a reliable comparison. The variety of providers and methods trained, ensured a comprehensive picture of gamification approaches in Lean Construction trainings.

In the observed trainings, participants work in teams and have to realise projects with different levels of complexity. The main variable in all of these trainings is the degree of 
abstraction to which the tasks differs from actual construction processes. Examples are realistic models of houses, made out of different materials as bricks or tools, or more abstract tasks, where the teams have to assemble tools, or boxes which are not necessarily reminiscent of construction projects.

The trainings often follow the same patterns: Ahead of the first round, the participants receive information about different roles within the project teams. Information on the task and desired goals, such as a maximum assembly time, desired quality or a budget is given. The first round begins and the facilitators interact with the project teams and raise, some a little more, some a little less, the pressure on the project teams. The teams can usually not fulfil the tasks within the desired time, quality or budget. Following this first round, participants conduct a review of the processes and issues and rank their performance as well as the level of cooperation. Similarities with actual construction projects are identified and issues such as supply chain problems, the lack of enough construction time, technical issues and a high stress levels are discovered as reasons for the non-fulfilment of tasks. Afterwards, the consultants present a specific Lean Construction method. This method is applied in a second round, to fulfil a very similar or even same task as in the first round, with more or less support by the consultants. Usually, the project teams can finish the projects much better than in the first round. In a review process about this second round, the participants identify the improvements, that were made through the application of the Lean Construction method.

Some trainings carry out further rounds to practice or refine the Lean Construction methods. The apparent goal of these trainings is to impart the knowledge about Lean Construction methods, but also to motivate participants to apply them to their construction projects. This might be amplified through the experiences from the first rounds, with failed and uncomfortable processes, and the success of the rounds, where Lean Construction approaches were applied.

Observing the trainings in the role of complete observers we analysed the theoretical structure and practical implementation of the trainings in a double-blinded process. Resulting from the observation, we identified the following game design elements within Lean Construction training:

Table 1: game design elements used in Lean Construction training

\begin{tabular}{|c|c|}
\hline Game element & Implementation in Lean Construction training \\
\hline Challenge & The team has to finish a task within requested time, budget and quality \\
\hline Cooperation & $\begin{array}{l}\text { The work of each team member is necessary to win the challenge, without } \\
\text { cooperation within the team it will fail }\end{array}$ \\
\hline Feedback loops & $\begin{array}{l}\text { After each round, participants receive feedback on their work to foster progress } \\
\text { for the next round }\end{array}$ \\
\hline Levels & Participants solve the task in two to three rounds of different complexity \\
\hline $\begin{array}{l}\text { Performance } \\
\text { graphs }\end{array}$ & A matrix of teamwork and processes reflects individual progress \\
\hline Points & The construction of parts per minute is measured \\
\hline Roles & $\begin{array}{l}\text { Each team member is assigned a different task and contributes to the goal in a } \\
\text { different way e.g. as a main- or sub-contractor }\end{array}$ \\
\hline Teams & Participants work in teams of $4-8$, trying to achieve one common goal \\
\hline Time pressure & $\begin{array}{l}\text { Participants have a fixed amount of time to fulfil the task, the time limit is too } \\
\text { ambitious for the first round, using additional time costs money }\end{array}$ \\
\hline
\end{tabular}


When using Gamification, the goal is to make an experience more game-like. With the analysed trainings, this was not the case, hence they cannot be described as gamified trainings yet. Table 1 shows nonetheless that a variety of game design elements are already implemented in such trainings. Taking these approaches further and intentionally designing Lean Construction training with game design elements to become more gamelike offers the chance to achieve the positive effects of gamification described above. Those can include further engagement of employees, raising a feeling of belonging to the team and being part of the mission. Thus, proactivity and employee interaction when using Lean Construction can be strengthened (Team 2017). The following conceptual framework offers guidance how to achieve these effects.

\section{CONCEPTUAL FRAMEWORK FOR THE APPLICATION OF GAMIFICATION IN LEAN CONSTRUCTION TRAINING}

For the implementation of gamification, very complex frameworks exist (see for example Chou (2016)). None of the gamification frameworks offered in gamification literature have been generally accepted so far. Each context for the application of gamification is different and the framework used should match the circumstances of the context. As gamification has not been used frequently in the construction industry, here, the focus is on simple application. With more experience, one can prospectively consider using more complex frameworks.

A universal definition about which game design elements can be used for gamification applications does not exist and can hardly be created (Werbach and Hunter 2012). Nevertheless, there are game design elements that are used particularly frequently and have been considered for the framework presented in this paper. Lists of game design elements can be found, inter alia, in the works of Sailer $(2016)^{1}$, Werbach and Hunter $(2012)^{2}$, Marczewski (2018) ${ }^{3}$, Wood and Reiners $(2015)^{4}$, Blohm and Leimeister (2013) ${ }^{5}$, Zichermann and Cunningham (2011) ${ }^{6}$ and Reeves and Read (2009) ${ }^{7}$. In the framework presented here, game design elements mentioned by at least two authors are considered. These provide a first overview and ideas for the use of elements. The extensibility of the list is explicitly pointed out. Table 2 lists game design elements, highlights their desired impact and offers an example how to implement them in Lean Construction trainings. The examples were derived from the observation of trainings and discussed with training providers. Definitions of game design elements are given according to Sailer (2016) ${ }^{1}$, Werbach and Hunter $(2012)^{2}$, Marczewski (2018) ${ }^{3}$ and Seaborn and Fels (2015) ${ }^{8}$. Both the listed game design elements and definitions are marked with superscript numbers indicating their source.

Table 2: game design elements used in Lean Construction training

\begin{tabular}{|c|c|c|c|}
\hline $\begin{array}{c}\text { Game design } \\
\text { element }\end{array}$ & $\begin{array}{l}\text { Observed in } \\
\text { trainings }\end{array}$ & Definition & Recommendation of use \\
\hline Avatars $1,2,5$ & & $\begin{array}{l}\text { Visual representation of the } \\
\text { user, identifying him }{ }^{*} \text { her }^{1}\end{array}$ & $\begin{array}{c}\text { Each team decides on a team name and } \\
\text { develops an avatar that represents their } \\
\text { team }\end{array}$ \\
\hline Badges ${ }^{1,2,3,4,5,6}$ & & $\begin{array}{l}\text { Visual icons signifying } \\
\text { achievements }^{1}\end{array}$ & $\begin{array}{l}\text { Badges can visualize the success in } \\
\text { certain areas, e.g. in time completion, in } \\
\text { budget completion, good teamwork }\end{array}$ \\
\hline Chance $^{2,4,6}$ & & Elements of randomness ${ }^{2}$ & $\begin{array}{l}\text { Roles of team members can be assigned } \\
\text { by chance, additional time or resources } \\
\text { can be won in a lottery kind of way (e.g. }\end{array}$ \\
\hline
\end{tabular}




\begin{tabular}{|c|c|c|c|}
\hline $\begin{array}{l}\text { Game design } \\
\text { element }\end{array}$ & $\begin{array}{l}\text { Observed in } \\
\text { trainings }\end{array}$ & Definition & Recommendation of use \\
\hline & & & $\begin{array}{l}\text { every five minutes each team draws an } \\
\text { event card indicating a new incident) }\end{array}$ \\
\hline Challenge ${ }^{2,3,4,5,6}$ & $\checkmark$ & $\begin{array}{l}\text { Element to make users feel like } \\
\text { they earned their achievement, } \\
\text { e.g. testing knowledge }{ }^{3}\end{array}$ & $\begin{array}{l}\text { Fulfilling the task (e.g. building a house } \\
\text { with game bricks) within the assigned } \\
\text { time range, budget and quality }\end{array}$ \\
\hline Collecting 2,3,5,6 & & $\begin{array}{l}\text { Items to collect, fostering } \\
\text { relationships and feelings of } \\
\text { purpose }\end{array}$ & $\begin{array}{c}\text { Building material has to be collected } \\
\text { through a team challenge like scavenger } \\
\text { hunt }\end{array}$ \\
\hline $\begin{array}{l}\text { Competition } \\
2,3,4,5,7\end{array}$ & & $\begin{array}{l}\text { Chance for users to prove } \\
\text { themselves against others }{ }^{3}\end{array}$ & $\begin{array}{l}\text { Teams compete against each other in } \\
\text { terms of time to complete task, number } \\
\text { of mistakes, budget and quality }\end{array}$ \\
\hline $\begin{array}{c}\text { Content } \\
\text { unlocking } 2,3,6\end{array}$ & & $\begin{array}{l}\text { Kind of achievement that offers } \\
\text { additional } \\
\text { information/guidelines/rewards } \\
3\end{array}$ & $\begin{array}{l}\text { Trading resources (e.g. time, bricks, } \\
\text { virtual currency) for additional help to } \\
\text { fulfil the task better }\end{array}$ \\
\hline $\begin{array}{l}\text { Cooperation } \\
2,4,5,6,7\end{array}$ & $\checkmark$ & $\begin{array}{c}\text { Team members or individual } \\
\text { users have to share } \\
\text { information/help each other to } \\
\text { be successful }{ }^{2}\end{array}$ & $\begin{array}{l}\text { Each team member performs a task that } \\
\text { is important for the overall task. Not } \\
\text { every team member has all the } \\
\text { information and/or authorisation to do } \\
\text { certain tasks, so cooperation is } \\
\text { necessary. }\end{array}$ \\
\hline $\begin{array}{l}\text { Feedback loops } \\
\qquad 2,3,4,6,7\end{array}$ & $\checkmark$ & $\begin{array}{l}\text { Mechanic that provides users } \\
\text { with information on their } \\
\text { progress }^{3}\end{array}$ & $\begin{array}{l}\text { Breaks in between rounds to provide } \\
\text { teams with feedback to review the } \\
\text { process and to improve the next task }\end{array}$ \\
\hline Gifting $2,3,4,6$ & & $\begin{array}{l}\text { Allowing users to share items } \\
\text { with other people/teams to } \\
\text { help them achieve goals }{ }^{3}\end{array}$ & $\begin{array}{l}\text { When working with limited resources } \\
\text { (e.g. Lego bricks), teams can gift left over } \\
\text { resources to other teams, teams can } \\
\text { support other teams by undertaking a } \\
\text { part of their tasks (e.g. construction site } \\
1 \text { has finished in time and uses their left- } \\
\text { over time to help construction site 2) }\end{array}$ \\
\hline $\begin{array}{l}\text { Leader-boards } \\
\qquad 1,2,3,4,6\end{array}$ & & $\begin{array}{c}\text { Display of ranks for comparison } \\
1\end{array}$ & $\begin{array}{l}\text { A team leader board displays the ranking } \\
\text { of the teams round after round showing } \\
\text { their position in the competition }\end{array}$ \\
\hline Levels $2,3,4,5,6,7$ & & $\begin{array}{l}\text { Increasingly difficult } \\
\text { environments, milestones } \\
\text { indicating progress }{ }^{3}\end{array}$ & $\begin{array}{l}\text { Two tasks of different difficulty, after } \\
\text { completing the first easy task, the more } \\
\text { difficult one can be started. }\end{array}$ \\
\hline $\begin{array}{l}\text { Narrative } \\
1,2,3,4,5,7\end{array}$ & $(\checkmark)$ & $\begin{array}{c}\text { Frame story, a story that is told } \\
1\end{array}$ & $\begin{array}{l}\text { A school building has to be finished } \\
\text { before holidays end }\end{array}$ \\
\hline $\begin{array}{l}\text { Performance } \\
\text { graph }^{1,2}\end{array}$ & $\checkmark$ & $\begin{array}{l}\text { Performance graphs graphically } \\
\text { show the performance of users } \\
\text { in an intra-individual } \\
\text { comparison over a certain } \\
\text { period of time. It is therefore a } \\
\text { dynamic display for visualising } \\
\text { one's own performance. }^{1}\end{array}$ & $\begin{array}{l}\text { A matrix of teamwork and processes } \\
\text { reflects individual progress }\end{array}$ \\
\hline Points $1,2,3,6$ & $\checkmark$ & $\begin{array}{l}\text { Numerical units indicating } \\
\text { progress }^{1}\end{array}$ & $\begin{array}{l}\text { Parts per minute in construction is } \\
\text { measured and used to compare the } \\
\text { results of the teams }\end{array}$ \\
\hline Rewards $2,3,6$ & & Tangible, desirable items ${ }^{3}$ & $\begin{array}{l}\text { Giving prospect of a desirable reward for } \\
\text { well performing teams, e.g. cake, beer or } \\
\text { other incentives }\end{array}$ \\
\hline
\end{tabular}




\begin{tabular}{|c|c|c|c|}
\hline $\begin{array}{c}\text { Game design } \\
\text { element }\end{array}$ & $\begin{array}{l}\text { Observed in } \\
\text { trainings }\end{array}$ & Definition & Recommendation of use \\
\hline Roles & $\checkmark$ & $\begin{array}{l}\text { Role-playing elements of } \\
\text { character }^{8}\end{array}$ & $\begin{array}{c}\text { Client, main contractor, sub-contractor, } \\
\text { assembly line worker }\end{array}$ \\
\hline Scarcity ${ }^{2,6}$ & & $\begin{array}{l}\text { Making something rare to make } \\
\text { it more desirable }\end{array}$ & $\begin{array}{l}\text { Different coloured Lego bricks stand for } \\
\text { different raw materials, not all are } \\
\text { available in equal quantities, rare raw } \\
\text { materials are popular }\end{array}$ \\
\hline Status $3,5,7$ & & $\begin{array}{c}\text { Textual monikers indicating } \\
\text { progress }^{\mathbf{3}}\end{array}$ & $\begin{array}{l}\text { By showing positive results in the tasks, } \\
\text { teams can earn higher status ranking } \\
\text { from lean construction newbie to lean } \\
\text { construction professional }\end{array}$ \\
\hline Teams $^{2,3,6,7}$ & $\checkmark$ & $\begin{array}{l}\text { Working in groups to foster } \\
\text { collaboration }^{3}\end{array}$ & $\begin{array}{l}\text { Participants work in teams of } 4-8 \text { people } \\
\text { and try to achieve one common goal, } \\
\text { help and advice within the team is } \\
\text { mandatory to fulfil the task }\end{array}$ \\
\hline$\underset{3,5,7}{\text { Time pressure }}$ & $\checkmark$ & $\begin{array}{l}\text { Fixed amount of time for users } \\
\text { to fulfil a task }{ }^{3}\end{array}$ & $\begin{array}{l}\text { Fixed amount of time to fulfil task, too } \\
\text { ambitious for first round, additional time } \\
\text { costs virtual goods }\end{array}$ \\
\hline $\begin{array}{l}\text { Virtual goods } \\
\qquad 2,4,5\end{array}$ & & $\begin{array}{l}\text { Game assets with perceived or } \\
\text { real-money value }{ }^{2}\end{array}$ & $\begin{array}{l}\text { A virtual currency (e.g. poker chips) is } \\
\text { used to trade bricks or buy additional } \\
\text { time }\end{array}$ \\
\hline Win states 2,5 & & $\begin{array}{l}\text { Objects that make the group } \\
\text { winner }{ }^{2}\end{array}$ & Definition of milestones \\
\hline
\end{tabular}

When implementing game design elements like the examples mentioned above, a good mix of different stimuli is important. Not every user is motivated by competition. Some users will work best if they can collaborate with teammates and have a focus on relationship fostering elements. When planning a gamification application, it is important to ensure a balanced use of game design elements.

\section{CONCLUSIONS AND RECOMMENDATIONS}

The aim of this study is to improve Lean Construction implementation efforts through innovative and motivating training concepts. The study offers an overview of the need for systematic change management processes including training to ensure successful Lean Construction implementation. Observations of Lean Construction trainings were analysed and game design elements were explored. The findings indicate that Lean Construction trainings offer great potential to intentionally use gamification in their context. It is concluded that the concept of gamification is suited to tackle barriers in the implementation of Lean Construction. This is in line with publications that have already analysed the potential of serious games for Lean Construction training, but have not conducted this with a large sample size.

We present a conceptual framework as a guideline for further applications of gamification components to improve Lean Construction trainings. With this explorative approach we aim to contribute to the improvement of change management processes in lean construction. Motivating and varied training enables employees to apply Lean Construction. The empowerment of employees promotes improved results in Lean Construction projects.

Further work is required to develop and analyse a gamified Lean Construction training. The study established research questions for further research on gamification in Lean Construction. We recommend to develop and analyse case studies intentionally using 
gamification by using game design elements in a structured way. The analysis of their effect in trainings would offer further valuable insights for the application of gamification in Lean Construction.

\section{REFENRENCES}

Balogun, J., and V. H. Hailey. (2008). Exploring strategic change, Harlow: FT Prentice Hall Financial Times.

Blohm, I., and J. M. Leimeister. (2013). "Gamification: Design of IT-Based Enhancing Services for Motivational Support and Behavioral Change." Bus Inf Syst Eng, 5(4): 275-278. doi.org/10.1007/s12599-013-0273-5.

By, R. T. (2005). "Organisational change management: A critical review." Journal of Change Management, 5(4): 369-380. doi.org/10.1080/14697010500359250.

Chou, Y.-K. (2016). Actionable gamification: Beyond points, badges, and leaderboards, Fremont, CA: Octalysis Media.

Demirkesen, S., N. Wachter, S. Oprach, and S. Haghsheno. (2019). "Identifying Barriers in Lean Implementation in the Construction Industry." In Proc., 27th Annual Conference of the International Group for Lean Construction (IGLC), Annual Conference of the International Group for Lean Construction: 157-168.

Deterding, S., D. Dixon, R. Khaled, and L. Nacke. (2011a). "From game design elements to gamefulness." In Proc., the 15th International Academic MindTrek Conference, edited by A. Lugmayr, H. Franssila, C. Safran, and I. Hammouda: 9, New York, New York, USA.

Deterding, S., D. Dixon, R. Khaled, and L. Nacke. (2011b). "Gamification: Toward a Definition." In paper at the CHI 2011, Vancouver.

Fiedler, M., ed. (2018). Lean Construction - das Managementhandbuch: Agile Methoden und Lean Management im Bauwesen, Berlin: Springer Gabler.

Hamari, J., J. Koivisto, and H. Sarsa. (2014). "Does Gamification Work? -- A Literature Review of Empirical Studies on Gamification." In Proc., 2014 47th Hawaii International Conference on System Sciences (HICSS): 3025-3034.

Kotter, J. P. (1996). Leading Change, Boston: Harvard Business School Press.

Lauer, T. (2010). Change Management: Grundlagen und Erfolgsfaktoren, Heidelberg: Springer-Verlag GmbH.

Liker, J. K., and J. M. Morgan. (2006). "The Toyota Way in Services: The Case of Lean Product Development." AMP, 20(2): 5-20. doi.org/10.5465/amp.2006.20591002.

Liu, C., V. A. González, J. Liu, Z. Rybkowski, A. Schöttle, C. Mourgues Álvarez, and I. Pavez. (2020). "Accelerating the Last Planner System ${ }^{\circledR}$ (LPS) Uptake Using Virtual Reality and Serious Games: A Sociotechnical Conceptual Framework." In Proc., 28th Annual Conference of the International Group for Lean Construction (IGLC), Annual Conference of the International Group for Lean Construction: 481-492.

Marczewski, A. (2018). Even Ninja Monkeys Like to Play: Gamification, game thinking and motivational design, [S. 1.: Independently published].

McGonigal, J. (2012). Reality is broken: Why games make us better and how they can change the world; [includes practical advice for gamers], London: Vintage Books.

Morschheuser, B., L. Hassan, K. Werder, and J. Hamari. (2018). "How to design gamification? A method for engineering gamified software." Information and Software Technology, 95: 219-237. doi.org/10.1016/j.infsof.2017.10.015.

Rechsteiner, A. (2020). "Die Geschichte der Videospiele".

Sacks, R., A. Esquenazi, and M. Goldin. (2007). "LEAPCON: Simulation of Lean Construction of High-Rise Apartment Buildings." Journal of Construction 
Engineering and Management, 133(7): 529-539. doi.org/10.1061/(ASCE)07339364(2007)133:7(529).

Sailer, M. (2016). Die Wirkung von Gamification auf Motivation und Leistung, Wiesbaden: Springer Fachmedien Wiesbaden.

Salem, O., J. Solomon, A. Genaidy, and I. Minkarah. (2006). "Lean Construction: From Theory to Implementation." J. Manage. Eng., 22(4): 168-175. doi.org/10.1061/(ASCE)0742-597X(2006)22:4(168).

Schaffer, R., and Harvey. (1992). "Successful Change Programs Begin with Results." Successful Change Programs Begin with Results (hbr.org) (Feb. 12, 2021).

Schewe, G. (2018). "Definition Change Management." Die Seite wurde nicht gefunden Gabler Wirtschaftslexikon (Dec. 8, 2018).

Schöpper, H., F. Dörries, and S. Lodeman. (2019). "Der Gamification Effekt: Wie Sie Ihr Unternehmen mit Hilfe von motivierenden Spiel-Elementen wettbewerbsfähiger und digitaler machen." Mittelstand 4.0-Kompetenzzentrum Hamburg.

Seaborn, K., and D. I. Fels. (2015). "Gamification in theory and action: A survey." International Journal of Human-Computer Studies, 74: 14-31. doi.org/10.1016/j.ijhcs.2014.09.006.

Song, X. (2009). "Why Do Change Management Strategies Fail? - Illustrations with case studies." Journal of Cambridge Studies 4 (1). statista. (2020). "Computerspieler Anzahl in Deutschland bis 2020.".

Team, G. (2017). "Acht Vorteile der Gamifizierung Ihres Betriebs." Acht Vorteile der Gamifizierung Ihres Betriebs (game-learn.com) (Feb. 12, 2021).

Tommelein, I. D., D. R. Riley, and G. A. Howell. (1999). "Parade Game: Impact of Workflow Variability on Trade Performance". Journal of Construction Engineering and Management, 125(5): 304-310. doi.org/10.1061/(ASCE)0733-9364(1999)125:5(304).

Tsao, C., M. Azambuja, F. Hamzeh, C. Menches, and Z. K. Rybkowski. (2013). "Teaching lean construction: perspectives on theory and practice." Proc. 21st Annual Conference of the International Group for Lean Construction.

Werbach, K., and D. Hunter. (2012). For the win: How game thinking can revolutionize your business, Philadelphia: Wharton Digital Press.

Wood, L. C., and T. Reiners. (2015). "Gamification." In Encyclopedia of Information Science and Technology, Third Edition, edited by D. Khosrow-Pour: 3039-3047: IGI Global.

Zichermann, G., and C. Cunningham. (2011). Gamification by Design: Implementing Game Mechanics in Web and Mobile Apps, Sebastopol, CA: O'Reilly. 